\title{
Agonists and antagonists of GnRH-I and -II reduce metastasis formation by triple-negative human breast cancer cells in vivo
}

\author{
Antje Schubert - Thomas Hawighorst • \\ Günter Emons · Carsten Gründker
}

Received: 6 January 2011 / Accepted: 17 January 2011/Published online: 30 January 2011

(C) Springer Science+Business Media, LLC. 2011

\begin{abstract}
Metastasis to bone is a frequent problem of advanced breast cancer. Particularly breast cancers, which do not express estrogen and progesterone receptors and which have no overexpression/amplification of the HER2neu gene, so called triple-negative breast cancers, are considered as very aggressive and possess a bad prognosis. About $60 \%$ of all human breast cancers and about $74 \%$ of triple-negative breast cancers express receptors for gonadotropin-releasing hormone $(\mathrm{GnRH})$, which might be used as a therapeutic target. Recently, we could show that bonedirected invasion of human breast cancer cells in vitro is time- and dose-dependently reduced by GnRH analogs. In the present study, we have analyzed whether GnRH analogs are able to reduce metastases of triple-negative breast cancers in vivo. In addition, we have evaluated the effects of GnRH analogs on tumor growth. To quantify formation of metastasis by triple-negative MDA-MB-435 and MDAMB-231 human breast cancers, we used a real-time PCR method based on detection of human-specific alu sequences measuring accurately the amount of human tumor DNA in athymic mouse organs. To analyze tumor growth, the volumes of breast cancer xenotransplants into nude mice were measured. We could demonstrate that $\mathrm{GnRH}$ analogs significantly reduced metastasis formation by triple-negative breast cancer in vivo. In addition, we could show that $\mathrm{GnRH}$ analogs significantly inhibited the growth of breast cancer into nude mice. Side effects were not detectable. In conclusion, GnRH analogs seem to be suitable drugs for an efficacious therapy for triple-negative, GnRH receptor-
\end{abstract}

A. Schubert · T. Hawighorst · G. Emons · C. Gründker $(\bowtie)$ Department of Gynecology and Obstetrics, Georg-AugustUniversity, Robert-Koch-Street 40, 37075 Göttingen, Germany e-mail: grundker@med.uni-goettingen.de positive human breast cancers to prevent metastasis formation.

Keywords GnRH analogs - Metastasis - Breast cancer

\section{Introduction}

Breast cancer is the most frequent malignant disease in women, with more than 1,000,000 new cases and 370,000 deaths yearly worldwide [1]. About $75-80 \%$ of breast cancers are steroid hormone receptor-positive and express estrogen and/or progesterone receptors [2, 3]. Approximately $15-20 \%$ of breast cancers overexpress the HER2neu gene. Approximately half of these tumors co-express steroid hormone receptors. About $10-15 \%$ of breast cancers do not express estrogen and progesterone receptors and have no overexpression/amplification of the HER2-neu gene [4-6]. These so called triple-negative breast cancers are considered as very aggressive and have a bad prognosis. The most common organ for metastasis formation of breast cancer is bone, followed by lung and liver [7]. Bone metastases lead to hypercalcemia, bone pain, fractures, and nerve compression. They cause increased morbidity and mortality in patients with advanced breast cancer. Osteolytic metastases are most common in breast cancer, but mixed and osteoblastic metastases occur in a significant number of patients [8]. Between 60 and $70 \%$ of women who die from breast cancer have lung metastases. In $21 \%$ of cases, lung is the only site of metastasis $[9,10]$. Liver metastases develop in approximately 50\% of women with metastatic breast cancer, and are typically associated with metastases at other sites, indicating advanced disease and poor prognosis [11]. Breast cancer may also spread to other regions of the body. Though these sites are less common, 
breast cancer may infect brain, ovaries, spinal cord, eye, and other organs.

Between 50 and $60 \%$ of human breast cancers and in addition most breast cancer cell lines express receptors for gonadotropin-releasing hormone $(\mathrm{GnRH})$, also called luteinizing hormone releasing hormone (LHRH) [12-15]. About $74 \%$ of triple-negative breast cancers express GnRH receptors [unpublished results]. Previous work showed that nanomolar concentrations of GnRH-II antagonists induce apoptotic cell death in human endometrial, ovarian, and breast cancer cells in vitro and in vivo via stress-induced MAPKs p38- and JNK-induced activation of the proapoptotic protein Bax, loss of mitochondrial membrane potential, release of cytochrome $c$, and activation of caspase- 3 [16-18]. Furthermore, we demonstrated that GnRH-II antagonists bind to the GnRH-I receptor and are clear antagonists at the GnRH-I receptor [17]. Recently, we showed that invasion of breast cancer cells through an artificial basement membrane was increased when they were cocultured with human primary osteoblasts (hOB) [19]. The ability to invade the basement membrane and to migrate in response to the cellular stimulus was significantly reduced after treatment with GnRH analogs [19]. This effect was due to an indirect inhibition of expression of the osteoblast-derived chemokine stromal cell-derived factor-1 (SDF-1).

In the present study, we have analyzed whether GnRH analogs are able to reduce metastasis of triple-negative breast cancers in vivo. In addition, we have assessed the effects of GnRH analogs on tumor growth.

\section{Materials and methods}

\section{Cell lines and culture conditions}

The triple-negative but $\mathrm{GnRH}$ receptor-positive human breast cancer cell lines MDA-MB-435 and MDA-MB-231 were obtained from American Type Culture Collection (ATCC, Manassas, Virginia). In order to guarantee the identity of the cell lines over the years, the cells were expanded after purchase and aliquots were stored in liquid nitrogen. Every half year a new frozen stock was opened and expanded to carry out the experiments. The cells were cultured at $37^{\circ} \mathrm{C}$ in a humidified atmosphere of $5 \% \mathrm{CO}_{2}$ in air as previously described [20-22].

\section{GnRH analogs}

The GnRH-I agonist Triptorelin was kindly provided by Ferring Pharmaceuticals (Copenhagen, Denmark). The GnRH-I antagonist Cetrorelix was a gift from Aeterna Zentaris GmbH (Frankfurt, Germany). The GnRH-II agonist
[D-Lys ${ }^{6}$ ] GnRH-II and the GnRH-II antagonist [Ac-D-2Nal ${ }^{1}$, D-4Cpa $\left.{ }^{2}, \mathrm{D}-3 \mathrm{Pal}^{3,6}, \mathrm{Leu}^{8}, \mathrm{D}-\mathrm{Ala}^{10}\right] \mathrm{GnRH}-\mathrm{II}$ were developed by us and synthesized by Peptide Specialty Laboratories GmbH (Heidelberg, Germany).

Animals

Female athymic (nude) mice (CD1 nu/nu), 6-8 weeks old on arrival, were obtained from Charles River (Sulzfeld, Germany). The mice were housed in sterile cages in a temperature-controlled room with 12-h light/12-h dark schedule and were fed autoclaved chow and water ad libitum. All experiments were done according to the German ethical guidelines and the German laws for protection of animals and were approved by the Governmental Committee on Research Animal Care of the Lower Saxony State Office for Consumer Protection and Food Safety (Oldenburg, Germany).

Tumorigenesis and metastasis formation assay

MDA-MB-435 cells $\left(1 \times 10^{6}\right.$ cells/ $100 \mu 1$ serum-free culture medium) were injected bilaterally into the second mammary fat pads of athymic, female, 6-week-old CD1 nu/nu mice. Beginning from day 2 after tumor cell injection, the mice were treated without (control) or with $25 \mathrm{nmol}$ of GnRH-I agonist Triptorelin $(32.8 \mu \mathrm{g})$, GnRH-I antagonist Cetrorelix $(35.1 \mu \mathrm{g})$, GnRH-II agonist [D-Lys ${ }^{6}$ ]GnRH-II $(32.7 \mu \mathrm{g})$ or GnRH-II antagonist $\left[\mathrm{Ac}-\mathrm{D}-2 \mathrm{Nal}^{1}, \mathrm{D}-4 \mathrm{Cpa}^{2}, \mathrm{D}-3 \mathrm{Pal}^{3,6}, \mathrm{Leu}^{8}\right.$, D-Ala $\left.{ }^{10}\right] \mathrm{GnRH}-\mathrm{II}(35.6 \mu \mathrm{g})$. Treatment was repeated every 3 days. The smallest and largest tumor diameter were measured weekly using a digital caliper, and tumor volumes were calculated using the following formula: Volume $=4 / 3 \times \pi \times(1 / 2 \times \text { smaller diameter })^{2} \times 1 / 2 \times$ larger diameter.

Intracardiac injection of MDA-MB-231 cells was performed as described previously [23]. Briefly, subconfluent MDA-MB-231 cells were refed with fresh medium $24 \mathrm{~h}$ before injection. Cells $\left(1 \times 10^{5}\right)$ suspended in $0.1 \mathrm{ml}$ serum-free culture medium were injected with a 30 -gauge needle into the left cardiac ventricles of mice under anesthesia (ketamine hydrochloride, $100 \mathrm{mg} / \mathrm{kg}$ of body weight and xylazine hydrochloride, $4 \mathrm{mg} / \mathrm{kg}$ of body weight in physiological $\mathrm{NaCl}$ solution). Beginning from day 2 after tumor cell injection, the mice were treated without (control) or with $25 \mathrm{nmol}$ of GnRH-I agonist Triptorelin or GnRH-II antagonist [Ac-D-2Nal ${ }^{1}, \mathrm{D}-4 \mathrm{Cpa}^{2},{ }^{2} \mathrm{D}-3 \mathrm{Pal}^{3,6}, \mathrm{Leu}^{8}$, D-Ala $\left.{ }^{10}\right]$ GnRH-II. Treatment was repeated every 2 days.

After completion of the experiments the animals were killed and both thigh bones (femur) and the lungs were removed from each mouse and snap frozen in liquid nitrogen. 
Quantitative assessment of human tumor cell metastasis formation

The effects of GnRH analogs on metastasis formation by triple-negative breast cancers in vivo was quantified as described in detail previously [24]. Briefly, explanted lungs and thigh bones were immediately transferred into liquid nitrogen and stored until use. For isolation of genomic DNA, the DNEasy Blood and Tissue Kit (Qiagen, Hilden, Germany) was used according to the manufacturer's instructions. Total genomic DNA (murine and human) of the dilution series was subjected to quantitative real-time alu PCR. To detect human cells in the mouse tissue, primers (Eurogentec, Seraing, Germany) specific for the human alu sequences (sense: 5'-CAT GGT GAA ACC CCG TCT CTA3'; and antisense: 5'-GCC TCA GCC TCC CGA GTA G-3') were used to amplify the human alu repeats present in genomic DNA that was extracted from mouse tissue. The internal TaqMan probe for alu (5'-[YY]-ATT AGC CGG GCG TGG TGG C-[BHQ-1]-3') was 5'-labelled with the reporter fluorescent dye Yakima Yellow (YY) and carried the non-fluorescent quencher dye Black Hole Quencher-1 (BHQ-1). The 18S rRNA control kit (Eurogentec) was used as an internal reference according to the manufacturer's instructions. The internal probe for $18 \mathrm{~S}$ rRNA was labelled with the reporter dye 6-carboxy-fluorescein (FAM) at the $5^{\prime}$ end and the quencher dye 6-carboxy-tetramethyl-rhodamin (TAMRA) at the $3^{\prime}$ end. PCRs were carried out in $25 \mu \mathrm{l}$ using 2xTaqMan Universal PCR Master Mix (Applied Biosystems, Foster City, CA), $0.9 \mu \mathrm{M}$ each alu specific oligonucleotide primer, $250 \mathrm{nM}$ internal alu probe, $1.5 \mu \mathrm{l} 18 \mathrm{~S}$ rRNA primer mix (Eurogentec), $0.5 \mu$ internal 18S rRNA probe (Eurogentec), and $1 \mu$ genomic DNA. The final concentration for genomic DNA was $50 \mathrm{ng} / \mu \mathrm{l}$. PCR was carried out for $2 \mathrm{~min}$ at $50^{\circ} \mathrm{C}$ to activate uracil- $N$-glycosylase and for $10 \mathrm{~min}$ at $95^{\circ} \mathrm{C}$ to activate the polymerase followed by 40 cycles of $15 \mathrm{~s}$ at $95^{\circ} \mathrm{C}$ and $1 \mathrm{~min}$ at $600 \mathrm{C}$ using the ABI PRISM ${ }^{\mathrm{TM}} 7700$ Sequence Detector (Applied Biosystems). Serial dilution steps (1:10) of genomic DNA obtained from human MDA-MB-435 or MDA-MB-231 cells in genomic DNA obtained from either mouse thigh bones or lung tissue served to construct the calibration curves. The $a l u$ treshhold cycle (Ctalu), the cycle at which the alu PCR product becomes detectable above background signal, was determined for each dilution series. To correlate the amount of the alu PCR signal (and thereby the amount of human tumor cell metastasis) to the amount of amplified genomic DNA (and thereby the amount of bone and lung tissue, respectively), "housekeeping gene" 18S rRNA was used as an internal control against which the alu signal was normalized $(\Delta \mathrm{Ct}=\mathrm{Ctalu}-\mathrm{Ct} 18 \mathrm{~S}$ rRNA). A standard curve was generated for each measurement by using the real-time PCR assay and plotting $\Delta \mathrm{Ct}$ as a function of the relative amount of human DNA in murine DNA (\%). The R2 value (correlation coefficient) was $>0.96$ for all measurements demonstrating an excellent relationship between the alu signal and the relative amount of human DNA with a detection limit of $0.001 \%$ human DNA in murine DNA.

\section{Statistical analysis}

The data were tested for significant differences by one-way analysis of variance followed by Student-Newman-Keuls' test for comparison of individual groups, after a Bartlett test had shown that variances were homogenous. In the experiment analyzing lung metastasis formation (Fig. 4), variances were not homogenous and a Kruskal-Wallis test followed by a Dunns test for comparison of individual groups was applied.

\section{Results}

Effects of GnRH analogs on tumor growth in vivo

To show the influence of GnRH analogs on growth of triplenegative human breast cancers, nude mice bearing orthotopically growing human breast tumors were treated with GnRH-I agonist Triptorelin, GnRH-I antagonist Cetrorelix, GnRH-II agonist [D-Lys ${ }^{6}$ ]GnRH-II, or the GnRH-II antagonist. During the experiments, one mouse had to be excluded from control group starting from day 20 (2nd measuring day). The other mice were killed after 34 days. Side effects during therapy were not observed. The increase of the tumor volume of the mice receiving therapy with GnRH-I and GnRH-II analogs was lower than with the control animals (Fig. 1). Tumor growth was significantly inhibited already on day 16 (1st measuring day) in comparison to the control group $\left(62.67 \pm 9.91 \mathrm{~mm}^{3}\right)$ by treatment with [D-Lys ${ }^{6}$ ] GnRH-II $\left(25.38 \pm 10.58 \mathrm{~mm}^{3}, P<0.05\right.$ vs. control $)$ and also by treatment with the GnRH-II antagonist (17.12 \pm $6.08 \mathrm{~mm}^{3}, P<0.01 \mathrm{vs}$. control). In the further process of the experiment, the antitumor effects of both GnRH-II analogs continued to increase. After 24 days of treatment (3rd measuring day), the differences became highly significant $(P<0.001)$ and remained so. After completion of therapy on day 34 , the tumor volume of the mice that had received therapy with GnRH-II agonist and GnRH-II antagonist was reduced to one third of the tumor volume of the control animals (control group: $594.10 \pm 49.47 \mathrm{~mm}^{3}$, [D-Lys ${ }^{6}$ ] GnRH-II: $177.20 \pm 55.19 \mathrm{~mm}^{3}, P<0.001$ vs. control, GnRH-II antagonist: $158.60 \pm 43.87 \mathrm{~mm}^{3}, P<0.001$ vs. control). Treatment with GnRH-I agonist Triptorelin $\left(415.50 \pm 66.39 \mathrm{~mm}^{3}\right.$ on day 34 of treatment) and GnRH-I antagonist Cetrorelix (440.60 $\pm 78.07 \mathrm{~mm}^{3}$ on day 34 of 


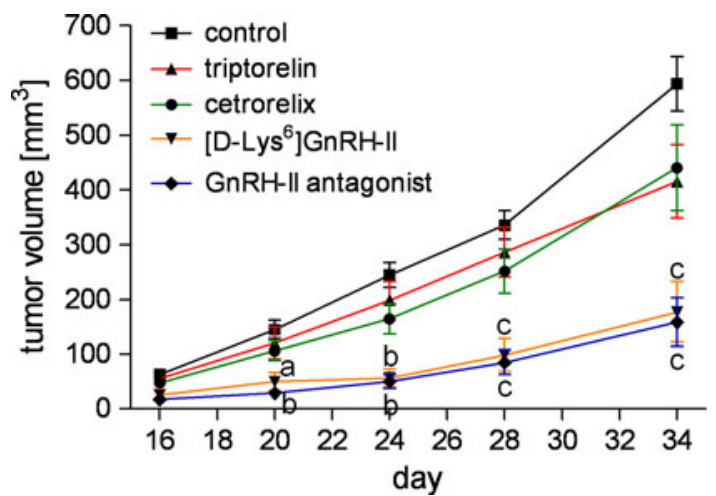

Fig. 1 Tumor volume of triple-negative MDA-MB-435 breast cancers xenografted bilaterally into the second mammary fat pads of female CD1 nu/nu mice. The mice were treated without (control) or with $25 \mathrm{nmol}$ of GnRH-I agonist Triptorelin, GnRH-I antagonist Cetrorelix, GnRH-II agonist [D-Lys ${ }^{6}$ ]GnRH-II or the GnRH-II antagonist. Treatment was repeated every 3 days. The mice were killed after 34 days. All experimental groups consisted of 5 animals (control $n=4$ as of day 20). Vertical bars represent SEM. a, $P<0.05$ versus control; b, $P<0.01$ versus control; c, $P<0.001$ vs. control

treatment) showed minor but not significant differences to the control group at any time.

Analysis of metastasis formation via alu real-time PCR

Metastasis formation by human breast cancer xenotransplants was quantified using TaqMan real-time PCR of human-specific alu sequences. In order to normalize the results, amplification of the housekeeping gene 18S rRNA was used as internal reference. To accurately quantify the amount of human tumor DNA in athymic mouse organs, a standard dilution row was used. It was set within a range of $100-0.0001 \%$ and carried out in each reaction run of the TaqMan real-time PCR (Fig. 2). If exactly the same quantity of DNA $(50 \mathrm{ng} / \mu \mathrm{l})$ was used, the fluorescence signal $\left(\Delta R_{\mathrm{n}}\right)$ of the housekeeping gene 18S rRNA remained identical during amplification (Fig. 2b). The human-specific alu sequence used showed fluorescence signals of a typical standard dilution row during amplification (Fig. 2a). Samples with fewer raw materials needed more cycles to the reach the same DNA quantity. If a standard dilution row of 1:10 was used, 3.3 additional cycles per dilution step are needed for amplification. The portion of human DNA in mouse DNA was determined in percentage. Each measurement was repeated twice.

Effects of GnRH analogs on bone metastasis formation by MDA-MB- 435 breast cancers in vivo

To quantify bone metastasis formation in nude mice bearing orthotopically growing MDA-MB-435 tumors, both thigh bones were taken from the animals and DNA was isolated afterward. The portion of human DNA in mouse DNA was quantified using alu real-time PCR. Five weeks after tumor cell injection, a significant increase of human-specific alu sequences in the thigh bones of the tumor-bearing mice could be detected (tumor group A: $8.16 \times 10^{-3} \pm 2.60 \times 10^{-3} \%$, $P<0.001$ vs. control group; tumor group B: $9.25 \times 10^{-3} \pm$ $2.58 \times 10^{-3} \%, \quad P<0.001$ vs. control group; control group A: $2.35 \times 10^{-4} \pm 0.73 \times 10^{-4} \%$; control group B: $2.20 \times 10^{-4} \pm 0.92 \times 10^{-4} \%$ ) (Fig. 3). Treatment with GnRH-I agonist Triptorelin $\left(2.48 \times 10^{-3} \pm 0.85 \times 10^{-3} \%\right.$, $P<0.01$ vs. tumor group), GnRH-I antagonist Cetrorelix $\left(5.98 \times 10^{-4} \pm 4.50 \times 10^{-4} \%, P<0.001\right.$ vs. tumor group $)$, GnRH-II agonist [D-Lys ${ }^{6}$ ]GnRH-II $\left(2.41 \times 10^{-3} \pm 1.50 \times\right.$ $10^{-3} \%, P<0.01$ vs. tumor group) and the GnRH-II antagonist $\left(7.42 \times 10^{-4} \pm 2.67 \times 10^{-4} \%, P<0.001\right.$ vs. tumor group) resulted in significant inhibition of metastasis formation in comparison to the tumor group.

Effects of GnRH analogs on lung metastasis formation by MDA-MB-435 breast cancers in vivo

To quantify lung metastasis formation in nude mice bearing orthotopically growing MDA-MB-435 tumors, the lungs were taken from the animals and DNA was isolated afterward. The portion of human DNA in mouse DNA was quantified using alu real-time PCR. Five weeks after tumor cell injection, an increase of human-specific alu sequences in the lungs of some tumor-bearing mice could be detected (tumor group A: $1.99 \times 10^{-1} \pm 1.69 \times 10^{-1} \%$, not significant vs. control group; tumor group B: $1.12 \times 10^{-1} \pm$ $0.98 \times 10^{-1} \%$, not significant vs. control group; control group A: $2.04 \times 10^{-6} \pm 1.27 \times 10^{-6} \%$; control group B: $17.64 \times 10^{-4} \pm 3.17 \times 10^{-4} \%$ ) (Fig. 4). Treatment with GnRH-I antagonist Cetrorelix $\left(2.43 \times 10^{-2} \pm 2.21 \times\right.$ $10^{-2} \%$, not significant vs. tumor group), GnRH-II agonist [D-Lys ${ }^{6}$ ] GnRH-II $\quad\left(1.02 \times 10^{-2} \pm 0.45 \times 10^{-2} \%, \quad\right.$ not significant vs. tumor group) and the GnRH-II antagonist $\left(3.71 \times 10^{-3} \pm 1.44 \times 10^{-3} \%\right.$, not significant vs. tumor group) resulted in a trend toward inhibition of metastasis formation in comparison to the tumor group. Unfortunately, due to large data dispersion these effects were not significant. No anti-metastatic effect was detectable using GnRH-I agonist Triptorelin $\left(4.71 \times 10^{-1} \pm 3.71 \times 10^{-1} \%\right.$, not significant vs. tumor group).

Effects of $\mathrm{GnRH}$ analogs on bone metastasis formation by MDA-MB-231 breast cancers in vivo

To quantify bone metastasis formation in nude mice after intracardiac injection of MDA-MB-231 breast cancer cells, both thigh bones were taken from the animals and DNA was isolated. The portion of human DNA in mouse DNA 
Fig. 2 Fluorescence signal of a standard dilution row of human DNA in mouse DNA during the run of one quantitative real-time PCR. The signal of the human alu sequence (a) was produced by Yakimo Yellow

$(\lambda=552 \mathrm{~nm})$, the signal of the housekeeping gene $18 \mathrm{~S}$ rRNA (b) by FAM $(\lambda=518 \mathrm{~nm})$. Fluorescence signals $\left(\Delta R_{\mathrm{n}}\right)$ during amplification, normalized against a passive reference (ROX), are shown
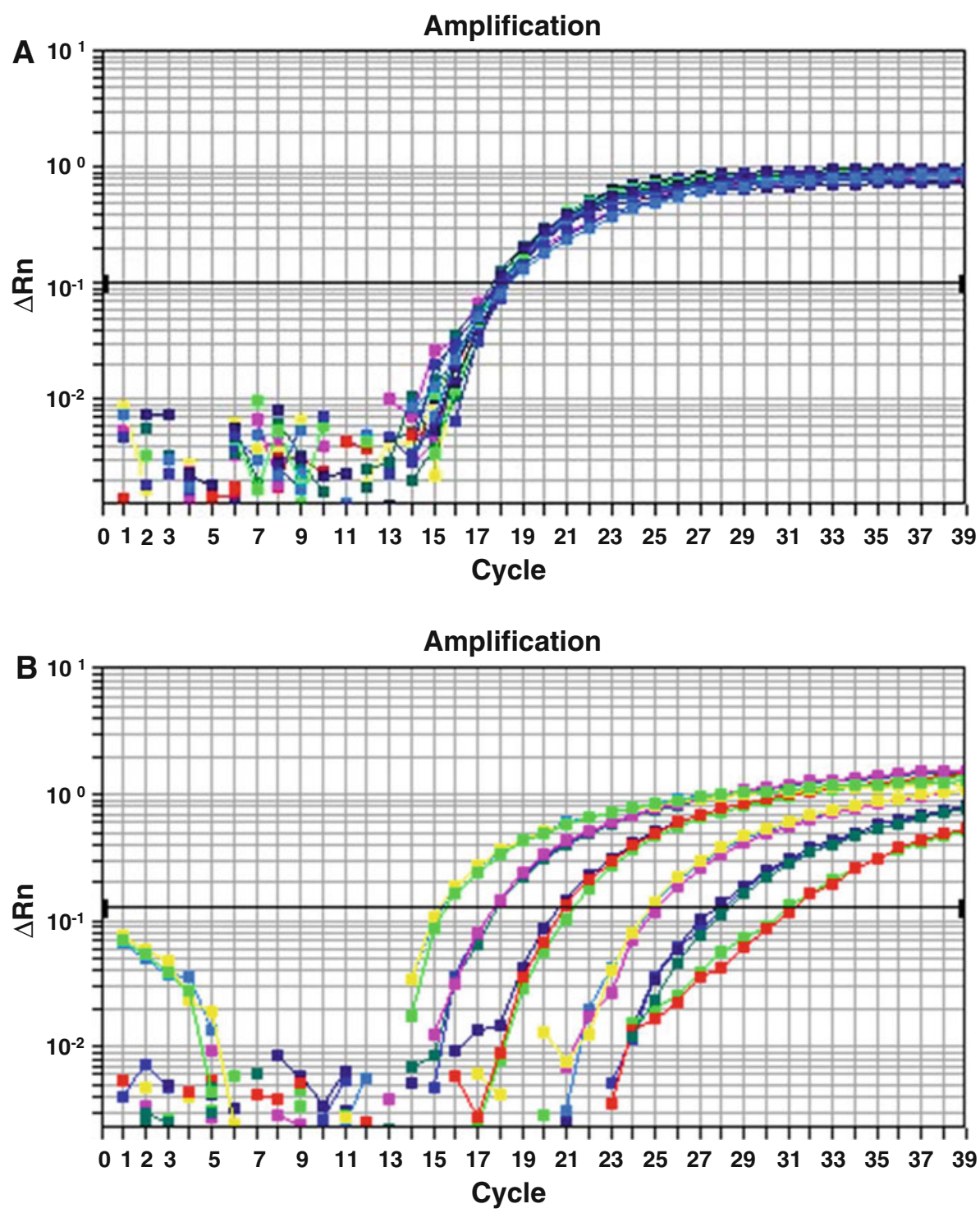

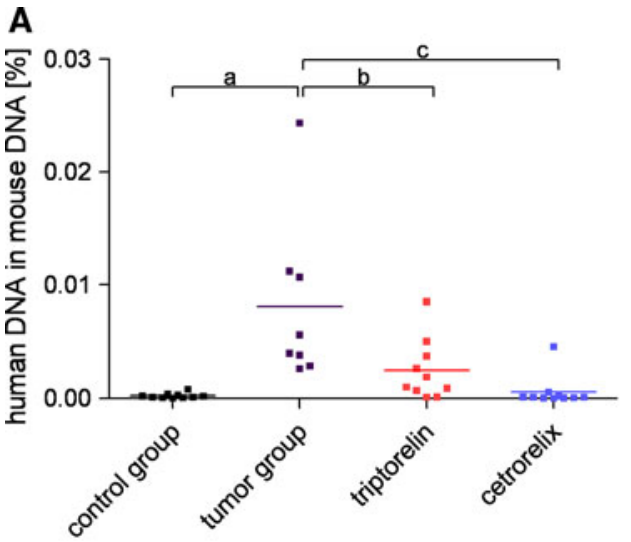

Fig. 3 Effects of GnRH-I/-II analogs on metastasis to thigh bones (femur) of MDA-MB-435 breast cancers xenografted bilaterally into the second mammary fat pads of female CD1 nu/nu mice. The mice were treated without (control) or with $25 \mathrm{nmol}$ of GnRH-I agonist Triptorelin, GnRH-I antagonist Cetrorelix, GnRH-II agonist [D-Lys ${ }^{6}$ ] GnRH-II or the GnRH-II

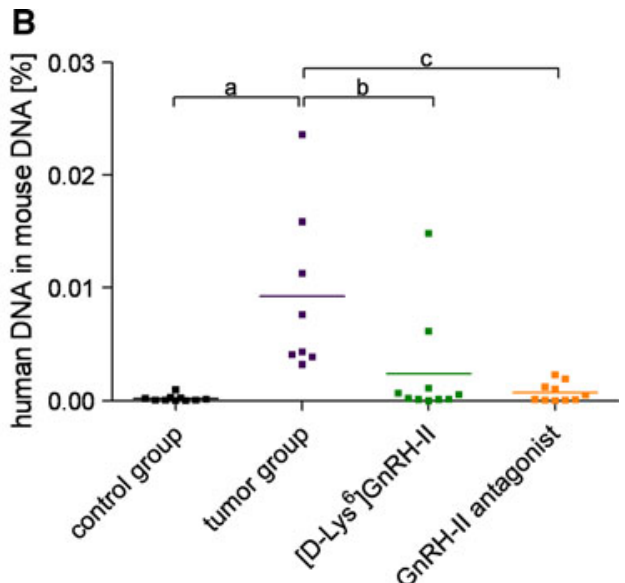

antagonist. Treatment was repeated every 3 days. The mice were killed after 34 days. Both thigh bones were removed and prepared separately from each mouse and analyzed. All experimental groups consisted of 5 animals (control $n=4$ as of day 20). Vertical bars represent SEM. a $P<0.001$ versus control, b $P<0.01$ versus tumor group, $\mathbf{c} P<0.001$ versus tumor group 


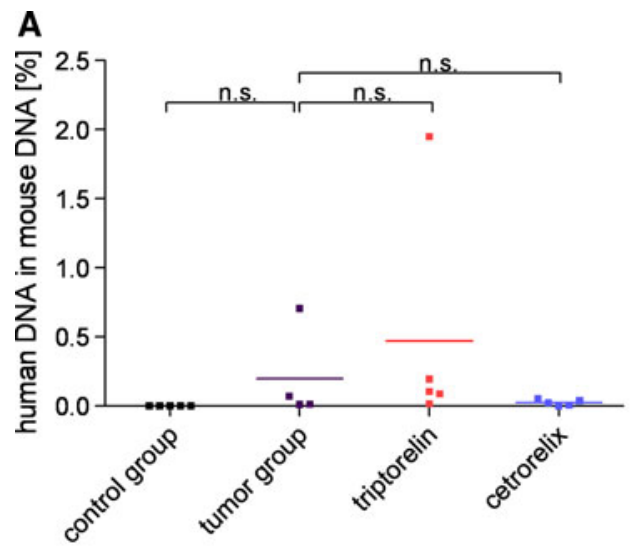

Fig. 4 Effects of GnRH-I/-II analogs on lung metastasis of MDAMB-435 breast cancers xenografted bilaterally into the second mammary fat pads of female CD1 nu/nu mice. The mice were treated without (control) or with $25 \mathrm{nmol}$ of GnRH-I agonist Triptorelin, GnRH-I antagonist Cetrorelix, GnRH-II agonist

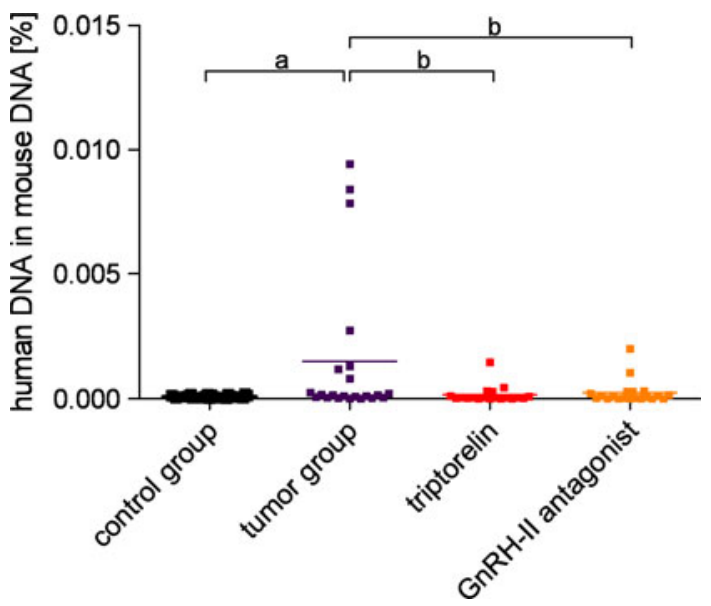

Fig. 5 Effects of GnRH-I/-II analogs on metastasis to thigh bones (femur) of circulating MDA-MB-231 breast cancer cells after intracardiac tumor cell injection into female CD1 nu/nu mice. The mice were treated without (control) or with $25 \mathrm{nmol}$ of GnRH-I agonist Triptorelin or the GnRH-II antagonist. Treatment was repeated every 2 days. The mice were killed after 34 days. Both thigh bones were removed and prepared separately from each mouse and analyzed. All experimental groups consisted of 10 animals. Vertical bars represent SEM. a $P<0.05$ versus control; b $P<0.05$ vs. tumor group

was quantified using alu real-time PCR. Five weeks after intracardiac tumor cell injection, a significant increase of human-specific alu sequences in the thigh bones could be detected (tumor group: $1.51 \times 10^{-4} \pm 0.63 \times 10^{-4} \%$, $P<0.05$ vs. control group; control group: $9.89 \times 10^{-5} \pm$ $1.18 \times 10^{-5} \%$ ) (Fig. 5). Treatment with GnRH-I agonist Triptorelin $\left(1.69 \times 10^{-5} \pm 7.74 \times 10^{-5} \%, P<0.05\right.$ vs. tumor group) and the GnRH-II antagonist $\left(2.45 \times 10^{-5} \pm\right.$ $1.08 \times 10^{-5} \%, P<0.05$ vs. tumor group) resulted in

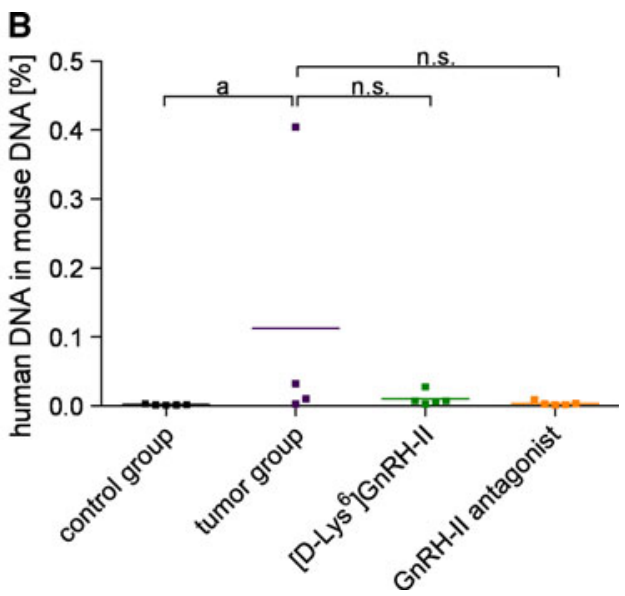

[D-Lys ${ }^{6}$ ]GnRH-II or the GnRH-II antagonist. Treatment was repeated every 3 days. The mice were killed after 34 days. All experimental groups consisted of five animals (control $n=4$ as of day 20). Vertical bars represent SEM. a $P<0.05$ versus control; n.s. not significant

significant inhibition of metastasis formation in comparison to the tumor group.

Lung metastases were not detectable 5 weeks after intracardiac injection of MDA-MB-231 breast cancer cells.

\section{Discussion}

Previous work had shown that breast cancer cell invasion through an artificial basement membrane in vitro was increased by coculture with human primary osteoblasts (hOB) or osteoblast-like sarcoma cells [19]. The ability to invade the basement membrane and to migrate in response to the cellular stimulus was significantly reduced after treatment with GnRH-I/-II analogs [19]. This effect was due to an inhibition of the stromal cell-derived factor-1 (SDF-1)/CXC motive chemokine receptor type 4 (CXCR4)-system [19]. A comparable anti-metastatic effect and mechanism was found for kisspeptin-10 (KP-10). KP-10 decreases bone-directed migration of kisspeptin receptor (KiSS1R, GPR54)-positive breast cancer cells in vitro through a direct inhibition of the prometastatic SDF-1/ CXCR4 system [25].

We now investigated the efficacy of systemic therapy with GnRH-I/-II analogs on both breast cancer growth and metastasis formation. We used MDA-MB-435 tumor cells representing a well-established orthotopic model system for the study of breast cancer metastasis formation. MDAMB-435 cells form primary tumors when injected into the mammary fat pad of nude mice, and spontaneously metastasize from these tumors to bone, lymph nodes, and lungs [26-29]. Several reports in the past suggested that the MDA-MB-435 cell line has a gene expression pattern most 
compatible with melanocytic origin $[30,31]$. In contrast, Sellappan et al. [32] demonstrated that the MDA-MB-435 cells express breast-specific and epithelial-specific markers. However, due to the obscure origin of the MDA-MB435 cells the use of this cell line in breast cancer research should be discussed. To date, the evidence from the literature rather suggests that the MDA-MB-435 cell line is of breast cancer origin, representing a poorly differentiated aggressive breast tumor line with expression of both epithelial and melanocytic markers [24].

In addition, we used MDA-MB-231 tumor cells. These cells were originally derived from a pleural effusion of a Caucasian breast cancer patient. However, orthotopically growing MDA-MB-231 xenotransplants do not develop metastases. Therefore, we used intracardiac injection of MDA-MB-231 cells to simulate circulating tumor cells.

We now could show that GnRH-I/-II analogs significantly inhibit bone metastasis formation by MDA-MB-435 triplenegative breast cancer cells grown as xenotransplants into the mammary gland of nude mice and of circulating MDAMB-231 triple-negative breast cancer cells after intracardiac injection. Inhibition of lung metastasis by treatment with GnRH-I/-II analogs in nude mice bearing orthotopically growing MDA-MB-435 tumors could be shown, but was not statistically significant due to large data variation. GnRH-I/II analogs reduce development of metastases not only from orthotopically growing breast cancers (MDA-MB-435) but also from circulating breast cancer cells (MDA-MB-231). This indicates that GnRH-I/-II analogs might not only have an influence on the first steps of breast cancer metastasis including epithelial-mesenchymal transition, migration, and invasion as known from in vitro data [19], but also on the biology of circulating breast cancer cells.

In addition to the antimetastatic activity of GnRH-I/-II analogs, we could demonstrate that analogs of GnRH-II but not of GnRH-I significantly inhibited tumor growth of orthotopically xenotransplanted MDA-MB-435 triple-negative breast cancers. In a recent article, we could show that GnRH-II antagonists induce apoptosis in MCF-7 and triplenegative MDA-MB-231 breast cancer cells in vitro and in vivo [18]. GnRH-I antagonist cetrorelix was already shown to induce inhibitory effects on triple-negative breast cancers in vitro and in vivo [33].

Moretti et al. [34] could demonstrate antiproliferative and antimetastatic activity of GnRH agonists on GnRH receptor-positive human melanoma cells. Gnanapragasam et al. [35] found that prostate GnRH receptors mediate a direct anti-tumorigenic reponse to GnRH analog therapy in hormone refractory prostate cancer. GnRH agonist treatment blocked prostate cancer cell proliferation and in addition the ability to invade a basement membrane in response to fibroblast growth factor (FGF). In another study Yates et al. [36] could show that GnRH antagonist
Cetrorelix inhibited the proliferation of human prostate cancer cells and restored their cell-cell adhesion and thus reduced prostate cancer cell invasion. These antimetastatic effects of GnRH analogs in vitro [34-36] and our recently shown in vitro results [19] could be now corroborated in vivo for the first time.

In conclusion, our findings show that GnRH-I/-II analogs decrease the ability of breast cancers to develop metastases. Therefore, the use of GnRH-I/-II analogs might be a novel antimetastatic therapeutic approach and should be further explored.

Acknowledgments This study was supported by the Deutsche Krebshilfe-Dr. Mildred Scheel Stiftung, grant 107224. We thank Sonja Blume, Renate Dietrich, and Matthias Läsche for excellent technical assistance. We are grateful to Ferring Pharmaceuticals (Copenhagen, Denmark) for supplying the GnRH-I agonist Triptorelin and to Aeterna Zentaris (Frankfurt, Germany) for the gift of the GnRH-I antagonist Cetrorelix.

Conflict of interest None.

\section{References}

1. Ferlay J, Bray F, Pisani P, Parkin DM (2001) GLOBOCAN 2000: cancer incidence, mortality and prevalence worldwide, version 1.0. IARC CancerBase No. 5. IARC Press, Lyon

2. Dawson SJ, Provenzano E, Caldas C (2009) Triple negative breast cancers: clinical and prognostic implications. Eur J Cancer 45(1):27-40

3. Konecny G, Pauletti G, Pegram M, Untch M, Dandekar S, Aguilar Z, Wilson C, Rong HM, Bauerfeind I, Felber M, Wang HJ, Beryt M, Seshadri R, Hepp H, Slamon DJ (2003) Quantitative association between HER-2/neu and steroid hormone receptors in hormone receptor-positive primary breast cancer. J Natl Cancer Inst 95(2):142-153

4. Kim MJ, Ro JY, Ahn SH, Kim HH, Kim SB, Gong G (2006) Clinicopathologic significance of the basal-like subtype of breast cancer: a comparison with hormone receptor and Her2/neuoverexpressing phenotypes. Hum Pathol 37(9):1217-1226

5. Nielsen TO, Hsu FD, Jensen K, Cheang M, Karaca G, Hu Z, Hernandez-Boussard T, Livasy C, Cowan D, Dressler L, Akslen LA, Ragaz J, Gown AM, Gilks CB, van de Rijn M, Perou CM (2004) Immunohistochemical and clinical characterization of the basal-like subtype of invasive breast carcinoma. Clin Cancer Res 10(16):5367-5374

6. Bauer KR, Brown M, Cress RD, Parise CA, Caggiano V (2007) Descriptive analysis of estrogen receptor (ER)-negative, progesterone receptor (PR)-negative, and HER2-negative invasive breast cancer, the so-called triple-negative phenotype: a population-based study from the California cancer Registry. Cancer 109(9):1721-1728

7. Lacroix M (2006) Significance, detection and markers of disseminated breast cancer cells. Endocr Relat Cancer 13(4):10331067

8. Guise TA, Kozlow WM, Heras-Herzig A, Padalecki SS, Yin JJ, Chirgwin JM (2005) Molecular mechanisms of breast cancer metastases to bone. Clin Breast Cancer 5(Suppl 2):S46-S53

9. Tomin R, Donegan WL (1987) Screening for recurrent breast cancer-its effectiveness and prognostic value. J Clin Oncol 5(1): $62-67$ 
10. Schlappack OK, Baur M, Steger G, Dittrich C, Moser K (1988) The clinical course of lung metastases from breast cancer. Klin Wochenschr 66(17):790-795

11. Selzner M, Morse MA, Vredenburgh JJ, Meyers WC, Clavien PA (2000) Liver metastases from breast cancer: long-term survival after curative resection. Surgery 127(4):383-389

12. Fekete M, Wittliff JL, Schally AV (1989) Characteristics and distribution of receptors for [D-TRP6]-luteinizing hormonereleasing hormone, somatostatin, epidermal growth factor, and sex steroids in 500 biopsy samples of human breast cancer. J Clin Lab Anal 3(3):137-147

13. Baumann KH, Kiesel L, Kaufmann M, Bastert G, Runnebaum B (1993) Characterization of binding sites for a GnRH-agonist (buserelin) in human breast cancer biopsies and their distribution in relation to tumor parameters. Breast Cancer Res Treat 25(1):37-46

14. Moriya T, Suzuki T, Pilichowska M, Ariga N, Kimura N, Ouchi N, Nagura H, Sasano H (2001) Immunohistochemical expression of gonadotropin releasing hormone receptor in human breast carcinoma. Pathol Int 51(5):333-337

15. Mangia A, Tommasi S, Reshkin SJ, Simone G, Stea B, Schittulli F, Paradiso A (2002) Gonadotropin releasing hormone receptor expression in primary breast cancer: comparison of immunohistochemical, radioligand and Western blot analyses. Oncol Rep 9(5):1127-1132

16. Fister S, Günthert AR, Emons G, Gründker C (2007) Gonadotropin-releasing hormone type II antagonists induce apoptotic cell death in human endometrial and ovarian cancer cells in vitro and in vivo. Cancer Res 67(4):1750-1756

17. Fister S, Günthert AR, Aicher B, Paulini KW, Emons G, Gründker C (2009) GnRH-II antagonists induce apoptosis in human endometrial, ovarian, and breast cancer cells via activation of stress-induced MAPKs p38 and JNK and proapoptotic protein Bax. Cancer Res 69(16):6473-6481

18. Gründker C, Föst C, Fister S, Nolte N, Günthert AR, Emons G (2010) Gonadotropin-releasing hormone type II antagonist induces apoptosis in MCF-7 and triple-negative MDA-MB-231 human breast cancer cells in vitro and in vivo. Breast Cancer Res 12(4):R49

19. von Alten J, Fister S, Schulz H, Viereck V, Frosch KH, Emons G, Gründker C (2006) GnRH analogs reduce invasiveness of human breast cancer cells. Breast Cancer Res Treat 100:13-21

20. Emons G, Ortmann O, Becker M, Irmer G, Springer B, Laun R, Hölzel F, Schulz KD, Schally AV (1993) High affinity binding and direct antiproliferative effects of LHRH analogues in human ovarian cancer cell lines. Cancer Res 53(22):5439-5446

21. Emons G, Schröder B, Ortmann O, Westphalen S, Schulz KD, Schally AV (1993) High affinity binding and direct antiproliferative effects of luteinizing hormone-releasing hormone analogs in human endometrial cancer cell lines. J Clin Endocrinol Metab 77(6):1458-1464

22. Irmer G, Bürger C, Müller R, Ortmann O, Peter U, Kakar SS, Neill JD, Schulz KD, Emons G (1995) Expression of the messenger RNAs for luteinizing hormone-releasing hormone (LHRH) and its receptor in human ovarian epithelial carcinoma. Cancer Res 55(4):817-822

23. Sasaki A, Boyce BF, Story B, Wright KR, Chapman M, Boyce R, Mundy GR, Yoneda T (1995) Bisphosphonate risedronate reduces metastatic human breast cancer burden in bone in nude mice. Cancer Res 55(16):3551-3557

24. Koch M, Hussein F, Woeste A, Gründker C, Frontzek K, Emons G, Hawighorst T (2010) CD36-mediated activation of endothelial cell apoptosis by an N-terminal recombinant fragment of thrombospondin-2 inhibits breast cancer growth and metastasis in vivo. Breast Cancer Res Treat. doi:10.1007/s10549-010-1085-7

25. Olbrich T, Ziegler E, Türk G, Schubert A, Emons G, Gründker C (2010) Kisspeptin-10 inhibits bone-directed migration of GPR54positive breast cancer cells: evidence for a dose-window effect. Gynecol Oncol 119(3):571-578

26. Castillo-Pichardo L, Martinez-Montemayor MM, Martinez JE, Wall KM, Cubano LA, Dharmawardhane S (2009) Inhibition of mammary tumor growth and metastases to bone and liver by dietary grape polyphenols. Clin Exp Metastasis 26(6):505-516

27. Price JE, Polyzos A, Zhang RD, Daniels LM (1990) Tumorigenicity and metastasis of human breast carcinoma cell lines in nude mice. Cancer Res 50(3):717-721

28. Welch DR (1997) Technical considerations for studying cancer metastasis in vivo. Clin Exp Metastasis 15(3):272-306

29. Skobe M, Hawighorst T, Jackson DG, Prevo R, Janes L, Velasco P, Riccardi L, Alitalo K, Claffey K, Detmar M (2001) Induction of tumor lymphangiogenesis by VEGF-C promotes breast cancer metastasis. Nat Med 7(2):192-198

30. Ross DT, Scherf U, Eisen MB, Perou CM, Rees C, Spellman P, Iyer V, Jeffrey SS, Van de Rijn M, Waltham M, Pergamenschikov A, Lee JC, Lashkari D, Shalon D, Myers TG, Weinstein JN, Botstein D, Brown PO (2000) Systematic variation in gene expression patterns in human cancer cell lines. Nat Genet 24(3):227-235

31. Ellison G, Klinowska T, Westwood RF, Docter E, French T, Fox JC (2002) Further evidence to support the melanocytic origin of MDA-MB-435. Mol Pathol 55(5):294-299

32. Sellappan S, Grijalva R, Zhou X, Yang W, Eli MB, Mills GB, Yu D (2004) Lineage infidelity of MDA-MB-435 cells: expression of melanocyte proteins in a breast cancer cell line. Cancer Res 64(10):3479-3485

33. Buchholz S, Seitz S, Schally AV, Engel JB, Rick FG, Szalontay L, Hohla F, Krishan A, Papadia A, Gaiser T, Brockhoff G, Ortmann O, Diedrich K, Koster F (2009) Triple-negative breast cancers express receptors for luteinizing hormone-releasing hormone (LHRH) and respond to LHRH antagonist cetrorelix with growth inhibition. Int J Oncol 35(4):789-796

34. Moretti RM, Montagnani Marelli M, Van Groeninghen JC, Limonta P (2002) Locally expressed LHRH receptors mediate the oncostatic and antimetastatic activity of LHRH agonists on melanoma cells. J Clin Endocrinol Metab 87(8):3791-3797

35. Gnanapragasam VJ, Darby S, Khan MM, Lock WG, Robson CN, Leung HY (2005) Evidence that prostate gonadotropin-releasing hormone receptors mediate an anti-tumourigenic response to analogue therapy in hormone refractory prostate cancer. J Pathol 206(2):205-213

36. Yates C, Wells A, Turner T (2005) Luteinising hormone-releasing hormone analogue reverses the cell adhesion profile of EGFR overexpressing DU-145 human prostate carcinoma subline. Br J Cancer 92(2):366-375 